\title{
Possible Role of Endotoxin in Mediating Host Resistance
}

\author{
Daniela N. Männel \\ Institut für Immunologie und Genetik, Deutsches Krebsforschungszentrum, D-6900 Heidelberg, Federal Republic of Germany
}

\begin{abstract}
Summary. Macrophages activated in a variety of ways in vivo as well as in vitro release a cytotoxic factor upon LPS stimulation. Physicochemical characterization revealed a heat-stable $60,000 \mathrm{D}$ protein with an isoelectric point at $\mathrm{pH} 4.8$. This cytotoxin is one of the effector molecules in tumor cell killing by activated macrophages since cytolysis can be inhibited by antibodies directed against the cytotoxic factor.
\end{abstract}

Key words: Cytotoxic Factor - Lymphokines - Host Resistance - Tumor-cytotoxicity - Lipopolysaccharides

\section{Introduction}

The endotoxic principle of lipopolysaccharides (LPS) from gramnegative bacteria seems to reside in its Lipid A component [1]. The administration of LPS or Lipid A into a susceptible host provokes a range of biological effects. Some of these effects can be attributed to direct actions of LPS on targets in the host organism. The majority of host responses, however, is mediated by soluble factors elicited upon the LPS stimulus. The production of interferon, colony stimulating factor and lymphocyte activating factor - to mention just a few activities - can be demonstrated after LPS application to the appropriate host [2-4]. Such mediators have been subject of intensive modern research and they have been shown to modulate immune reactions by acting on the immune system in sometimes complex ways (for review see $[5,6]$ ).

\section{Characterization of Endotoxin-Induced Cytotoxic Factor}

We studied the induction and properties of one mediator with a rather direct way of action. After administration of LPS to Mycobacterium bovis BCG-infected mice, the sera of these animals show cytotoxic activity for tumor cells in vivo (tumor necrosis factor) as well as in vitro [7, 8]. This cytotoxic activity is measured in vitro by label release of $\left[{ }^{3} \mathrm{H}\right]$ thymidine-prelabeled target cells after $48 \mathrm{~h}$ of incubation. Maximal titers of cytotoxic activity were detected $2 \mathrm{~h}$ after LPS treatment of mice which were infected with BCG 14 days before. Physicochemical characterization of the cytotoxic activity revealed a heat-stable $\left(56^{\circ} \mathrm{C}\right.$, 30 min) entity with a molecular weight of about 60,000 . The isoelectric point was at $\mathrm{pH} 4.8$ measured by flat bed isoelectric focusing. The activity of the cytotoxin was lost after treatment with protease, trypsin and chymotrypsin, but was not altered by the serine esterase inhibitor diisopropyl fluorophosphate. Physcicochemical characteristics reported for the tumor necrosis factor were very similar. However, the isolated $60,000 \mathrm{D}$ cytotoxin failed to induce tumor necrosis in vivo [9] and, therefore, cannot by itself be responsible for the necrotic effect after LPS administration.

\section{Cytotoxic Factor as Effector Molecule for Macrophage Cytotoxicity}

Release of cytotoxic factor was shown to be T-cell independent but dependent on Lipid A sensitivity. Serum of BCG-infected, T-cell deficient nude mice developed strong cytotoxic activity after LPS treatment, whereas no cytotoxicity could be measured in lipid A resistent $\mathrm{C} 3 \mathrm{H} / \mathrm{HeJ}$ mice. In in vitro experiments, macrophages were identified as cellular sources of this cytotoxin. Mac-

Table 1. Correlation between macrophage tumoricidal activity and release of cytotoxic factor

\begin{tabular}{|c|c|c|c|}
\hline \multirow{2}{*}{$\begin{array}{l}\text { Macrophages } \\
\text { from mice } \\
\text { treated with }\end{array}$} & \multirow{2}{*}{$\begin{array}{l}\text { Macrophage } \\
\text { tumoricidal } \\
\text { activity }^{2}\end{array}$} & \multicolumn{2}{|c|}{$\begin{array}{l}\text { Release of cytotoxic } \\
\text { factor }^{b}\end{array}$} \\
\hline & & - LPS & + LPS \\
\hline $\mathrm{BCG}$ & $2,240 \pm 130(26)$ & $470 \pm 20(11)$ & $1,410 \pm 60(33)$ \\
\hline Pyran & $2,380 \pm 250(27)$ & $640 \pm 10(15)$ & $1,600 \pm 110(38)$ \\
\hline C. parvum & $2,020 \pm 130(23)$ & $560 \pm 20(13)$ & $1,640 \pm 80(39)$ \\
\hline PBS & $770 \pm 70$ & $340 \pm 30 \quad(8)$ & $480 \pm 60(11)$ \\
\hline Starch & $620 \pm 20$ & $360 \pm 80$ & $360 \pm 60$ \\
\hline Latex & $790 \pm 10$ & $340 \pm 40$ & $400 \div 60$ \\
\hline No macrophages & $680 \pm 70$ & \multicolumn{2}{|c|}{$220 \pm 70 \quad(5)$} \\
\hline SDS total counts & $8,740 \pm 700(100)$ & \multicolumn{2}{|c|}{$4,250 \pm 170(100)$} \\
\hline
\end{tabular}

a Adherent peritoneal exudate cells from mice treated i.p. with $2 \times 10^{6}$ viable $\mathrm{BCG}, 500 \mu \mathrm{g}$ of pyran, $1.4 \mathrm{mg}$ of $C$. parmum, $2 \%$ starch in water, or latex beads 7 days previously or with PBS 1 day previously were incubated with $\left[{ }^{3} \mathrm{H}\right] \mathrm{T} \mathrm{dR}$-prelabeled tumor cells. Cytotoxicity (released $\left[{ }^{3} \mathrm{H}\right] \mathrm{TdR}$ ) was estimated at $48 \mathrm{~h}$ and expressed as mean counts per minute \pm SEM for duplicate cultures and as percentage of SDS total counts (in parentheses)

b For release of cytotoxic factor, the cytotoxic activity of 2-h supernatants from $10^{6}$ adherent peritoneal exudate cells with or without $10 \mu \mathrm{g}$ E. coli K 235 LPS was tested on $\left[{ }^{3} \mathrm{H}\right] \mathrm{TdR}$-prelabeled $\mathrm{L} 929$ cells. Cytotoxicity (released $\left[{ }^{3} \mathrm{H}\right] \mathrm{TdR}$ ) was estimated at $48 \mathrm{~h}$ and expressed as mean counts per minute \pm SEM for duplicate cultures and as percentage of SDS total counts (in parentheses) 
Tabje 2. Inhibition of macrophage cytotoxicity by IgG against serumderived cytotoxic factor

\begin{tabular}{llcc}
\hline Mouse strain & Stimulus & \multicolumn{2}{l}{ Cytotoxicity $^{\mathrm{a}}$} \\
\cline { 3 - 4 } & & $\operatorname{IgG}^{\mathrm{b}}$ & Medium \\
\hline C3H/HeN & BCG & $480 \pm 50(40)$ & $1,060 \pm 40(89)$ \\
& Pyran & $560 \pm 30(47)$ & $1,030 \pm 90(86)$ \\
& C. partum & $770 \pm 30(64)$ & $1,070 \pm 80(90)$ \\
C57BL/6N & BCG & $470 \pm 40(40)$ & $780 \pm 100(65)$ \\
Spontaneous release & & $170 \pm 10(14)$ \\
SDS total counts & & \multicolumn{2}{c}{$1,200 \pm 90(100)$} \\
\hline
\end{tabular}

a Adherent peritoneal exudate cells from mice treated i.p. with $2 \times 10^{6}$ viable BCG. $500 \mu \mathrm{g}$ of pyran, or $1.4 \mathrm{mg}$ of C. partum 7 days previously were incubated with $\left[{ }^{3} \mathrm{H}\right] \mathrm{TdR}$-labeled tumor cells at a $10: 1$ effector: target ratio. Cytotoxicity was estimated by $\left[{ }^{3} \mathrm{H}\right] \mathrm{TdR}$ release at $48 \mathrm{~h}$ and expressed as mean counts per minute \pm SEM for duplicate cultures and as percentage of SDS total counts (in parentheses)

b Purified IgG against cytotoxic factor at a final concentration of $0.5 \mathrm{mg} / \mathrm{ml}$ was added to the cultures

rophage enriched peritoneal exudate cells from $\mathrm{BCG}$ infected animals as well as macrophage-like tumor cells (PU 5-1.8) and peritoneal macrophages propagated in vitro with macrophage growth factor were able to release the cytotoxic factor upon LPS stimulus [10].

Activation of the macrophages and minute amounts of LPS as trigger were absolute requirements for factor release as shown in Table 1. Besides the in vivo activation with BCG, Pyran or C. parum, treatment in vitro with lymphokines containing macrophage activating factor also resulted in cytotoxic macrophages that were susceptible for induction of cytotoxic factor release by LPS. Tumoricidal activity of the macrophages correlated well with the ability to release soluble cytotoxin independent on the method of activation.

A rabbit antiserum against partially purified serum cytotoxic factor inhibited the cytotoxic activity of serum-derived as well as in vitro elicited factor [11]. When purified IgG directed against the cytotoxin was added to cultures of cytotoxic macrophages and tumor cells, macrophage cytotoxicity was markedly reduced (Table 2). Again. not only the cytotoxicity of in vivo activated macrophages but also of lymphokine activated macrophages was inhibited. The inhibitory effect of the antibodies was not due to damage of the cytotoxic effector cell since other macrophage functions like antibody-mediated cytotoxicity or chemotaxis were not affected and activated macrophages remained cytotoxic after removal of the antibody.

It seems to be clear from these studies that this cytotoxic factor is at least one of the effector molecules in tumor cell killing by activated macrophages. Also, sufficiently activated macrophages are well known to be antimicrobial [12]. The same serum that contains the tumoricidal activity was also shown to enhance resistance to bacterial infections [13]. Of course, the cytotoxic serum described here also displays a multitude of other LPS induced activities and it remains to be investigated if the cytotoxic factor plays a role in microbicidal activity of activated macrophages.

\section{Discussion}

From these and many other studies it becomes obvious that administration of LPS or lipid $A$ to an infected animal has tremendous effects. Current evidence is consistent with the hypothesis that during infection macrophages become activated by lymphokines that are secreted by specifically sensitized $T$ lymphocytes. This can be mimiked by activating macrophages for tumoricidal activity with lymphokines in vitro. These activated macrophages seem to be exquisitly sensitive to LPS-action judged by the extremly small amounts necessary as stimulus.

We have shown in our studies that LPS acts like a trigger on the activated macrophage and it induces a burst of cytotoxic activity within less than $2 \mathrm{~h}$. It needs to be clarified in the future if protection in one or the other model system can be ascribed to just one of the LPS induced mediators or if protection is rather the result of concerted action of various factors with the immune cells. Three different pathways of LPS action in the sensitized animal can be shown: 1) the direct effect of Lipid A on cells, 2) executive functions of LPS-induced mediators and 3) intercellular communication and modulation of the immune system via LPS-elicited lymphokines.

\section{References}

1. Galanos C, Lüderitz O, Rietschel ET. Westphal O (1977) In: Goodwin TW (ed) Biochemistry of Lipids II, vol 14, University Press, Baltimore, pp 239-335

2. Butler RC, Abdelmoor AM, Nowotny A (1978) Bone marrow colony-stimulating factor and tumor resistance-enhancing activity of postendotoxin mouse sera. Proc Natl Acad Sci USA $75: 2893-2896$

3. Youngner JS, Salvin SB (1973) Production and properties of migration inhibitory factor and interferon in the circulation of mice with delayed hypersensitivity. J Immunol 111:1914-1922

4. Männel DN, Farrar JJ, Mergenhagen SE (1980) Separation of a serum-derived tumoricidal factor from a helper factor for plaqueforming cells. I Immunol 124:1106-1110

5. Microbiology 1980, D Schlessinger (ed). ASM Washington DC

6. Biochemical Characterization of Lymphokines. In: De Weck AL, Kristensen F, Landy $M$ (eds) Proceedings of the second International Lymphokine Workshop (1980) Academic Press, New York London

7. Carswell WA, Old LJ, Kassel RL, Green S, Fiore N, Williamson $B$ (1975) An endotoxin-induced serum factor that causes necrosis of tumors. Proc Natl Acad Sci USA 72:3666-3670

8. Männel DN, Melzer MS, Mergenhagen SE (1980) Generation and characterization of a lipopolysaccharide-induced and serum-derived cytotoxic factor for tumor cells. Infect Immun $28: 204-211$

9. Kull FC, Cuatrecasas P (1981) Preliminary characterization of the tumor cell cytotoxin in tumor necrosis serum. J Immunol $126: 1279-1283$

10. Männel DN, Moore RN, Mergenhagen SE (1980) Macrophages as a source of tumoricidal activity (tumor necrosis factor). Infect Immun 30:523-530

11. Männel DN, Falk W, Meltzer SE (1981) Inhibition of nonspecific tumoricidal activity by activated macrophages with antiserum against a soluble cytotoxic factor. Infect Immun 33:156-164

12. North RJ (1978) The concept of the activated macrophage. J Immunol 121:806-809

13. Parant MA, Parant Fy and Chedid LA (1980) Enhancement of resistance to infections by endotoxin-induced serum factor from Mycobacterium bovis BCG-infected mice. Infect Immun $28: 654-659$ 